\title{
PERAN HUMAS DALAM MENINGKATKAN LOYALITAS STAKEHOLDERS UNIVERSITAS AHMAD DAHLAN
}

\author{
Choirul Fajri \\ Prodi Ilmu Komunikasi, Universitas Ahmad Dahlan \\ choirul.fajri@comm.uad.ac.id
}

\begin{abstract}
Universitas Ahmad Dahlan (UAD) have formed the public relations as liaison to outsiders (spokesman). With the UAD's Public Relations, expected various public interest and the interests of the organization can run together. Programs and strategy has been conducted by UAD's Public Relations to have good relations with stakeholders of UAD. This research own, intended to see how the role of public relations UAD to bolster loyalty of stakeholders. By using the case study method, with data collection method using focus group disscussion, it is hoped the result of research is could become basic to improving UAD's Public Relations. This research result indicates that public relations are expected to draw up strategies appropriate to enhance loyalty stakeholders, both in terms of the management of its own organization, communication pattern, and management of media connection.
\end{abstract}

\begin{abstract}
Abstrak
Universitas Ahmad Dahlan (UAD) telah membentuk bidang kehumasan sebagai penghubung dengan pihak luar (juru bicara). Dengan adanya Humas UAD tersebut, diharapkan berbagai kepentingan publik dan kepentingan organisasi dapat berjalan bersama. Berbagai program maupun strategi telah dilakukan oleh Humas UAD untuk menjalin hubungan baik dengan pihak-pihak (stakeholders) UAD. Penelitian ini sendiri, dimaksudkan untuk mengetahui bagaimana peran humas UAD guna meningkatkan loyalitas dari stakeholders. Dengan menggunakan metode studi kasus, dengan metode pengumpulan data dengan menggunakan focus group disscussion, diharapkan hasil dari penelitian ini dapat dijadikan acuan untuk perbaikan kinerja humas UAD itu sendiri. Hasil penelitian ini menunjukkan bahwa humas diharapkan mampu menyusun strategi-strategi yang tepat untuk dalam meningkatkan loyalitas stakeholders, baik dari segi pengelolaan organisasi sendiri, komunikasi yang dijalankan, dan pengelolaan media komunikasinya.
\end{abstract}

Keywords: Public Relations, Loyalty, Stakeholders 


\section{PENDAHULUAN}

Hubungan masyarakat (humas) memegang peranan penting bagi kesuksesan perusahaan. Menilikfungsi humas itu sendiri, yakni fungsi manajemen yang membangun serta mempertahankan hubungan baik dan bermanfaat antara organisasi dengan publik yang mempengaruhi kesuksesan atau kegagalan organisasi (Cutlip, Centr, dan Broom, 2006: 6).

Dari definisi tentang humas di atas, jelaslah bahwa humas memegang peranan penting dalam kaitannya untuk menjaga hubungan baik dengan publik. Setiap organisasi tentu saja membutuhkan pihakpihak lain untuk mencapai tujuannya. Oleh karenanya, humas diharapkan menjadi sebuah strategi yang dibangun guna menyeimbangkan kepentingan-kepentingan dari masing-masing pihak dengan kepentingan organisasi itu sendiri.

UniversitasAhmadDahlan(UAD)sebagai sebuah insitusi pendidikan yang merupakan amal usaha Muhammadiyah, selama ini juga telah melakukan berbagai strategi untuk terus memajukan organisasinya. Dari awal berdirinya hingga sekarang, UAD telah menglami perkembangan yang signifikan, di mana saat ini telah menjadi universitas besar yang memiliki 10 fakultas.

Perkembangan UAD tersebut tentu diimbangi dengan pertambahan jumlah mahasiswanya. Tiga tahun terakhir ini, tercatat kurang lebih 13.839 mahasiswa aktif di UAD. Jika kita lihat dari 10 tahun terakhir, jumlah mahasiswa UAD selalu mengalami peningkatan setiap tahunnya. Hanya pada tahun 2006 ini saja ketika gempa bumi menguncang Yogyakarta, jumlah mahasiswa mengalami penurun. Namun pada tahuntahun berikutnya jumlah mahasiswa UAD selalu meningkat. Seperti misalnya pada 3 tahun terakhir ini,. di tahun 2013 tercatat 7.132 orang yang mendaftarkan diri ke UAD, dan 4.632 orang melakukan registrasi. Pada tahun 2014, jumlah mahasiswa UAD juga mengalami peningkatan, tercatat 7.709 orang mendaftarkan diri ke UAD, dan 4.971 orang melakukan registrasi. Sementara pada tahun 2015 juga mengalami peningkatan, jumlah mahasiswa yang mendaftarkan diri ke UAD tercatat 13.004 orang, dan 5928 yang melakukan registrasi (Data diakses dari: http://sipenmaru.uad.ac.id/?mod=statistik $\mathrm{p}$ e $\mathrm{n} \mathrm{d}$ a f t a r \& s u b = s t a t i s t i k_ pendaftar\&do=daftar, 14 Juni 2016).

Dalam perspektif awam peneliti, peningkatan jumlah mahasiswa tersebut bisa jadimerupakan hasildarievent-eventpromosi dan kehumasan yang dilakukan oleh Humas Universitas Ahmad Dahlan. Universitas Ahmad Dahlan, sebagai sebuah organisasi besar juga telah membentuk humas sebagai sarana komunikasi dan menjalin hubungan baik dengan pihak luar. Hal ini, sebagaimana disebutkan dalam Peraturan Rektor UAD Nomor 3 Tahun 2012, tentang organisasi dan tata kerja unit-unit kerja UAD, pada Pasal 10 ayat 1 disebutkan bahwa tugas pokok Bidang Humas dan Protokoler adalah menjadi penghubung dengan pihak luar universitas (juru bicara universitas) dan membuat press release.

Seiring dengan perkembangan UAD yang semakin besar, sekarang ini bukan lagi pada sebatas bagaimana mencari mahasiswa dalam jumlah yang banyak, namun juga bagaimana meningkatkan loyalitas mahasiswa sebagai salah satu stakeholders UAD itu sendiri. Setiap pihak dalam organisasi pastilah mempunyai kepentinganyang berbeda-beda, misalnya saja di UAD ini. Di mana, karyawan menginginkan adanya tunjangan kesehatan, kenaikan gaji, pengurangan beban kerja, dan lainnya. Mahasiswa menginginkan adanya perbaikan sarana dan prasana, keringanan biaya pendidikan, maupun peningkatkan kualitas dosen. Sementara pihak luar, seperti halnya media membutuhkan sarana untuk mendapatkan berita-berita yang layak jual. Oleh karenanya, di sinilah humas UAD dapat memainkan peranannya untuk mensinergiskan kepentingan-kepentingan dari masing-masing pihak/civitas tersebut.

Humas sebagai representasi dari organisasi,yangdianggapmemilikikedekatan dengan masing-masing publik tentu harus menjadi penyeimbang antara kepentingan organisasi dengan kepentingan publik dalam 
organisasi itu sendiri sebagaimana telah disebutkan di atas. Fungsi humas sebagai check and balance terhadap kebijakan yang diambil organisasi bisa dimainkan, agar nantinya kebijakan tersebut bisa memperoleh dukungan dari semua pihak serta memberikan kemanfaatan bersama.

Selama ini humas UAD sendiri, telah berupaya untuk menjalin hubungan baik dengan berbagai pihak guna menyelaraskan kepentingan organisasi dengan kepentingan publik. Hal tersebut dilakukan Humas UAD dengan membuat berbagai strategi maupun program-program, seperti: pembentukan humas di masing-masing fakultas, publikasi di berbagai media, berbagai pelatihan dosen, kegiatan media relations (press gathering, press tour, press conference, dan lainnya), program kemitraan dengan Muhammadiyah (pengiriman programtelevisi TravelDiarydan Tafsir at Tanwir ke TvMuh), dan lainnya.

Selain untuk menjaga hubungan baik denganmasing-masingpublikataupuncivitas akademika di UAD sendiri, berbagai program yang dijalankan tersebut dimaksudkan pula untuk meningkatkan kinerja seluruh civitas akademika UAD. Dengan adanya peningkatkan kinerja tersebut, diharapkan dapatmencapaitujuanUADyakni, "Moraland Intelectual Integrity". Tanpa adanya dukungan dari civitas akademika, tentu saja cita-cita mulia UAD tersebut tidak akan berhasil. Oleh karenanya, dalam penelitian ini akan mencoba mengkaji tentang bagaimana peran Humas UAD guna meningkatkan kinerja dari civitas akademika untuk bersama-sama mencapai tujuan organisasi tersebut.

\section{KAJIAN PUSTAKA}

\section{Fungsi Public Relations}

Pada hakikatnya Public Relations adalah aktiftas. Oleh karenanya tujuan Public Relations dapat dianalogikan dengan tujuan komunikasi yakni adanya penguatan dan perubahan kognisi, apeksi dan prilaku komunikasintya. namun kata "relations" menunjukan kata kerja aktif maka harus dilihat dari dua kepentingan yaitu organisasi dan publik sehingga tujuan Public Relations adalah terpeliharanya dan terbentuknya saling penegrtian (aspek kognisi), menjaga dan membentuk saling percaya (aspek afeksi) dan memellihara serta menciptakan kerjasama (aspek psiomotoris).

Menurut Cutlip dan Center (2008:64), berikut ini adalah bagian-bagian dan fungsi Public Relations, satu, hubungan internal. Hubungan internal merupakan bagian khusus Public Relations yang membangun dan mempertahankan hubungan yang baik dan saling bermanfaat antara manajer dan karyawan tempat organisasi mengantungkan kesuksesannya.

Dua, publisitas. Publisitas merupakan sumber-sumber informasi yang disediakan oleh Public Relations dan digunakan oleh media karena informasi itu memiliki nilai berita. Metode penempatan pesan di media ini adalah pesan di media ini adalah metode yang tak bisa dikontrol (uncontrolled) sebab sumber informasi tidak memberi bayaran kepada media untuk pemuatan informasi tersebut.

Tiga, advertising. Informasi yang digunakan oleh Public Relations untuk menjangkau audien yang lebih luas, bukan untuk konsumen yang menjadi sasaran marketing, dimana informasi yang ditempatkan di media oleh sponsor tertentu yang jelas identitasnya yang membayar ruang dan waktu penempatan informasi tersebut. Ini adalah metode terkontrol dalam menempatkan pesan di media.

Empat, press agentry. Penciptaan berita dan peristiwa yang bernilai berita untuk menarik media massa dan mendapatkan perhatian publik. Banyak praktisi Public Relations kadang-kadang menggunakan taktik press agentry untuk menarik perhatian media kepada kliennya, organisasinya, atau tujuannya. Tetapi PR lebih dari sekedar press agentry.

Lima, public affairs. Bagian khusus dari Public Relations yang membangun dan mempertahankan hubungan pemerintah dan komunitas lokal dalam rangka memengaruhi kebijakan publik.

Enam, lobbying. Bagian khusus dari Public Relations yang berfungsi untuk 
menjalin dan memelihara hubungan dengan pemerintah terutama dengan tujuan memengaruhi penyusunan undang-undang dan regulasi.

Tujuh, manajemen isu. Proses proaktif dalam mengantisipasi, mengindentifikasi, mengevaluasi, dan merespon isu-isu kebijakan publik yang memengaruhi hubungan organisasi dengan publik mereka. Secara administratif atau secara konseptual, manajemen isu adalah bagian fungsi Public Relations, akan tetapi, jika dilihat sebagai komunikasi persuasif, dia menjadi taktik untuk memengaruhi kebijakan publik, bukan sebagai bagian dari perencanaan strategi organisasi.

Delapan, hubungan investor. Bagian dari Public Relations dalam perusahaan korporat yang membangun dan menjaga hubungan yang bermanfaat dan saling menguntungkan dengan shareholder dan pihak lain di dalam komunikasi keuangan dalam rangka memaksimalkan nilai pasar.

\section{Publik dalam Public Relations}

Publik merupakan salah satu objek kerja Public Relations, di mana seorang praktisi Public Relations mempunyai fungsi untuk menjembatani arus komunikasi antara perusahaan dengan publiknya. Publik dalam Publik Relations terdiri dari dua, yakni: publik internal dan eksternal. Publik internal, misalnya: karyawan, manager, maupun pemegang saham. Sedangkan publik eksternal, misalnua adalah komunitas, pemerintah, media, organisasi sosial, pemasok, dan lainnya.

Sebagai seorang staff Public Relations dituntut agar dapat mengetahui siapa saja yang menjadi publiknya dalam suatu organisasi. Publik dalam Public Relations sering kali disamakan dengan stake holder (pihak). Meskipun sebenarnya berbeda, namun dalam konteks ini publik dan pihak dalam suatu organisasi dapat disejajarkan, yakni mereka sama-sama dilayani ataupun dijembatani oleh berbagai kegiatan yang ada dalam Public Relations.

Pihak adalah kelompok-kelompok yang berkepentingan dengan aktivitas organisasi, dan lantaran berkepentingan maka kelompok-kelompok tersebut, mempengaruhi dan dipengaruhi oleh pencapaian tujuan perusahaan. (Wheelen dan Hunger, 1995: 6).

Pihak juga dapat diartikan sebagai setiap kelompok yang berada di dalam maupun di luar perusahaan yang mempunyai peran dalammenentukankeberhasilanperusahaan. (Kasali, 1994: 63).

Dari kedua pengertian mengenai pihak di atas, maka menurut peneliti pihak dapat diartikan sebagai publik, yang memiliki kepentinganlangsungataupuntidaklangsung dengan organisasi. Berbagai kepentingan tersebut tentunya sangat tergantung dari kebutuhan setiap publik itu sendiri.

\section{Teknologi dan Media Komunikasi}

Teori determinisme teknologidicetuskan pertama kali oleh Marshall Mc Luhan dengan pernyatannya berupa "the medium is message" artinya bahwa dampak yang paling penting dari media komunikasi adalah bahwa media komunikasi mempengaruhi kebiasaan persepsi dan berpikir kita (Severin dan Tankard, 2005:536).

Mc Luhan menggolongkan sejarah kehidupan manusia ke dalam empat periode: pertama, the tribal age (era suku atau purba). Pada era purba atau era suku zaman dahulu, manusia hanya mengandalkan indera pendengaran dalam berkomunikasi. Komunikasi pada era itu hanya mendasarkan diri pada narasi, cerita, dongeng tuturan, dan sejenisnya. Jadi, telinga adalah "raja" ketika itu, "hearing is believing", dan kemampuan visual manusia belum banyak diandalkan dalam komunikasi. Era primitif ini kemudian tergusur dengan ditemukannya alfabet atau huruf.

Kedua, the literate age (era literal/huruf). Semenjak ditemukannya alfabet atau huruf, maka cara manusia berkomunikasi banyak berubah. Indera penglihatan kemudian menjadi dominan di era ini, mengalahkan indera pendengaran. Manusia berkomunikasi tidak lagi mengandalkan tuturan, tapi lebih kepada tulisan. 
Ketiga, the print age (era cetak). Sejak ditemukannya mesin cetak menjadikan alfabet semakin menyebarluas ke penjuru dunia. Kekuatan kata-kata melalui mesin cetak tersebut semakin merajalela. Kehadiran mesin cetak, dan kemudian media cetak, menjadikan manusia lebih bebas lagi untuk berkomunikasi.

Keempat, the electronic age (era elektronik). Era ini juga menandai ditemukannya berbagai macam alat atau teknologi komunikasi. Telegram, telepon, radio, film, televisi, VCR, fax, komputer, dan internet. Manusia kemudian menjadi hidup di dalam apa yang disebut sebagai "global village". Media massa pada era ini mampu membawa manusia untuk bersentuhan dengan manusia yang lainnya, kapan saja, di mana saja, seketika itu juga.

Mc Luhan berpendapat, transisi antar periode tadi tidaklah bersifat gradual atau evolusif, akan tetapi lebih disebabkan oleh penemuan teknologi komunikasi. Teori determinisme teknologi menjelaskan bahwa teknologi media membentuk individu bagaimana cara berpikir dan berperilaku dalam masyarakat. Teknologi tersebut akhirnya mengarahkan manusia untuk bergerak dari satu abad teknologi ke abad teknologi lain. (Nurudin, 2003: 174).

Lebih lanjut ditegaskan oleh Shahram Amiri dan Brian Reif (2013: 50-60) bahwa saat ini meski televisi masih menjadi teknologi komunikasi yang belum tergantikan dan masih mampu bertahan dengan kemunculan media baru, namun internet telah menunjukkan tajinya yang mampu mengangkat perekonomian grassroot di sebuah wilayah.

\section{METODE}

Di dalam melaksanakan penelitian mengenai peran humas dalam meningkatkan loyalitas stakeholders ini, peneliti memilih menggunakan metode studi kasus. Metode studi kasus dipilih karenanya kemampuannya untuk mengangkat permasalahan-permasalahan empiris mengenai sebuah kasus. Menurut Baedowi dalam Salim (2006: 118), studi kasus sendiriadalah sebuah pendekatan yang digunakan untuk mempelajari, menerangkan, serta melakukan intepretasi terhadap fenomena dalam konteksnya yang alamiah tanpa adanya tekanan dari luar.

Sementara itu Wimmer dan Dominick (2006: 136), mengatakan bahwa penekanan studi kasus adalah apabila peneliti ingin memahami ataupun menjelaskan sebuah fenomenatertentu. Dengan memakaimetode studi kasus ini diharapkan peneliti mampu mendapatkan data secara riil dan mendalam. Oleh karenanya, berbagai pertanyaan yang diajukan nantinya lebih banyak "how" maupun "why”.

Dengan metode studi kasus ini, diharapkan peneliti memperoleh data yang sejelas-jelasnya mengenai proses managerial yang dilakukan oleh humas UAD dalam upayanya untuk meningkatkan loyalitas stakeholders. Aktivitas humas tersebut, akan dilihat secara detail baik dari proses perencanaannya, pelaksanaan, sampai kepada evaluasinya, sehingga nantinya akan mendapatkan sebuah kesimpulan tentang bagaimana selama ini peran humas dalam meningkatkan kinerja dari civitas akademika UAD.

Metode ini dilakukan dengan cara mengundang beberapa narasumber/pakar dalam satu waktu untuk saling berdiskusi. Hal ini dimaksudkan untuk mendapatkan sumbang saran/masukan/aspirasi mereka terkait dengan bagaimana mengoptimalkan fungsi humas UAD terutama dalam kaitannya dengan meningkatkan loyalitas stakeholders UAD. Adapun beberapa narasumber yang rencana akan peneliti undang untuk melakukan Focus Group Discussion ini, adalah sebagai berikut:

Dekan maupun wakil dekan, dan kepala program studi di lingkungan Universitas Ahmad Dahlan; Biro maupun Lembaga di Universitas Ahmad Dahlan; Kepala TU di Universitas Ahmad Dahlan; Perwakilan mahasiswa di Universitas Ahmad Dahlan 


\section{HASIL DAN PEMBAHASAN}

\section{Publisitas}

Hal pertamayang dilakukan Humas UAD dalam membuat publisitas adalah dengan membuat kalender kegiatan. Kalender yang menampilkan daftar kegiatan setiap fakultas maupun program studi sangat diperlukan untuk mendukung peningkatan publisitas di UAD. Humas UAD sendirisudah beberapa kali mengupayakan penyusunan ini, akan tetapi belum bisa berhasil. Mengingat ada beberapa hal yang menjadi kendala, diantaranya: agenda fakultas/prodi yang selama ini lebih banyak accidential (sehingga sulit untuk dibuat jadwal), memerlukan waktu yang cukup lama untuk mengumpulkan semua data kegiatan yang ada di fakultas/program studi. Ke depan pembuatan kalender ini memang menjadi salah satu prioritas dari program-program humas yang telah disusun.

Upaya lain yang dilakukan adalah dengan menjalin kerjasama dengan mediamedia, baik cetak maupun elektronik tentu mendukung publisitas. Selama ini Humas UAD sudah melakukan beberapa kerjasama dengan berbagai media, seperti: Harian Jogja, Seputar Indonesia, Republika, dan Jawa Pos. Kerjasama tersebut diwujudkan dalam bentuk pemuatan artikel-artikel popular dari dosen. Adanya kerjasama tersebut, terbukti dapat mendorong minat dari dosen untuk menampilkan karya-karya yang inovatif.

Oleh karenanya, adanya peningkatkan kerjasama dengan berbagai media juga menjadi hal yang harus diperhatikan, tidak terkecuali mencoba bekerjasama dengan media online, maupun media dengan skala nasional. Untuk mendukung terciptanya publisitas yang baik, civitas akademika UAD diharapkan mampu menangkap isu-isu yang sedang berkembang di masyarakat. Dosen sebagai kalangan akademisi, tentu dapat berperan dalam hal ini, untuk memberikan opini/argumentasinya mengenai isu-isu tersebut sesuai dengan kepakarannya masing-masing.

Dalam hal ini, humas berperan untuk aktif menginformasikan isu-isu yang sedang terjadi dan menginformasikannya kepada pakar-pakar yang dimiliki UAD, untuk memberikan pendapatnya yang kemudian dapat diteruskan di media-media yang ada. Peningkatan publisitas di media juga dilakukan melalui penyediaan reward kepada dosen-dosenyang artikelnya dimuat di media. Dosen-dosen tidak hanya mengandalkan media yang telah bekerjasama dengan UAD saja, namun juga media yang belum bekerjasama juga bisa menajdi sasaran.

Selain penyediaan reward, Humas UAD juga telah memberikan anggaran khusus bagi terlaksananya konferensi press yang diadakan oleh fakultas/prodi. Dana press konferensi dianggarkan $\mathrm{Rp}$ 1.400.000,-/3 bulan sekali. Dengan adanya dana tersebut, dapat digunakan untuk meningkatkan publisitas di tingkat prodi/fakultas, guna mengkomunikasikan hal-hal apa saja yang sedang dikerjakan oleh prodi/fakultas.

Tidak hanya masalah anggaran, namun tersedianya sumber daya manusia yang mumpuni juga merupakan salah satu faktor yang mendukung terlaksananya publisitas. Dalam hal ini upaya yang sudah dilakukan oleh Humas UAD, adanya dengan menyediakan reporter bagi setiap Humas Fakultas. Reporter tersebut diambil dari mahasiswa di fakultasnya masing-masing, yang diberikan reward bagi setiap peliputan yang dikerjakan. Meskipun demikian, keberadaan reporter ternyata belum bisa dimaksimalkan, mengingat kesibukkan dari reporter sendiri yang notabene masih mahasiswa, dan juga mengenai keterampilan jurnalistiknya yang masih perlu ditingkatkan. Ke depan adanya staff khusus yang dapat membantu tugas-tugas humas di masingmasing fakultas, nampaknya perlu dilakukan. Tugas-tugas dari SE Humas Fakultas sendiri, bisa dimanfaatkan, seperti: peliputan kegiatan, pembuatan berita, pengelolaan media komunikasi online (website, maupuh media social), dan lain sebagainya sehingga akan meningkatkan publisitas UAD sendiri.

\section{Manajemen Isu}

Banyak isu-isu yang berkembang di 
lingkungan internal sendiri. Sebagai salah satustakeholdersinternal, nampaknyaHumas masih sering abai untuk ikut menetralisir isu-isu yang sedang berkembang tersebut. Padahal humas sebagai representatif dari organisasi, dapat membantu mengkomunikasikan apa yang sesungguhnya terjadi kepada para stakeholders, sehingga mereka akan mampu memahami kondisi tersebut, dan berperan dalam memberikan informasi yang benar kepada pihak eksternal. Misalnya saja, saat itu adanya isu kenaikan pembayaran spp mahasiswa, atau pemindahan ruang kuliah, yang selama ini banyak menjadi perhatian khususnya para mahasiswa. Di sinilah humas dapat lebih aktif dalam mencari informasi yang akurat untuk kemudian mengkomunikasikannya dengan stakeholders internal, agar mereka mengetahui informasi tersebut dengan tepat dan tidak menimbulkan simpang siur yang dapat mengurangi kredibilitas lembaga itu sendiri.

Meksipun sudah ada lembaga yang dibentuk untuk memonitoring permasalahan-permasalahan yang ada di tingkat fakultas, yakni dengan adanya PSMF, namun humas dapat bersinergi untuk memastikan bahwa setiap keluhan/saran/kritik dari stakeholders internal (terutama mahasiswa sebagai klien kita) dapat tertampun dan terjawab dengan baik.

Adanya daftar kepakaran dari para dosendosen UAD sangatlah diperlukan, dalam upaya untuk melakukan sikap responsif terhadap isu-isu terkini yang sedang terjadi di masyarakat. Dalam daftar tersebut, diberikan informasi sejelas-jelasnya, mengenai: kontak pribadi, kompetensi bidang, maupun back ground pendidikan dan pengajarannya.

Terlebih jika daftar kepakaran tersebut, dapat dipublish untuk kebutuhan umum (tidak terkecuali para media) yang akan meliput (memintai pendapat) dari para pakar UAD tersebut, tentu hal ini dapat menaikkan citra UAD di masyarakat sendiri.

\section{Public Affair}

Adanya event-event pendidikan yang diselenggarakan oleh Kampus tentu dapat dimanfaatkan untuk soft promotion kepada pihak external yang ingin mencari informasi mengenai UAD. Selama ini event-event tersebut, diinisiasi sendiri oleh fakultas/ prodi, dan tidak teringrasi dengan baik. Di sinilah Humas UAD berkoordinasi dengan para fakultas/prodi agar event-event yang diselenggarakan dapat terintegrasi dengan baik, dan mendatangkan kemanfaatan yang lebih besar.

Salah satu tugas seorang humas, adalah mampu melaksanakan program sosial ke masyarakat sebagai sebuah tanggung jawab sosial kepada masyarakat. UAD telah banyak memberikan kontribusi kepada masyarakat melalui berbagai programnya, seperti: pemberian beasiswa, pemberian bantuan kepada guru-guru taman kanakkanak, pembangunan sekolah/tempat ibadah, menjadi sponsor suatu acara dan lain sebagainya. Maka di sinilah nama UAD semakin dikenal oleh masyarakat luas.

Adanya pertemuan rutin dari yang selenggarakan kampus para orang tua wali/ maba menjadi sebauh strategi yang perlu dilakukan oleh Humas UAD untuk menjalin kedekatan dengan para orang tua/wali mahasiswa. Komunikasi yang terjalin dengan baik ini diharapkan mampu memberikan support system bagi pengelolaan organisasi sendiri.

Selama ini beberapa fakultas/prodi sudah menyelenggarakan pertemuan dengan orang tua/wali mahasiswa itu sendiri, maka apabila sebenarnya event tersebut bisa dipadukan menjadi sebuah event kampus yang diselenggarakan oleh Humas UAD tentu akan memberikan kemanfaatan yang lebih besar.

Dalam acara tersebut, dapat dikemas untuk mengkomunikasi berbagai peristiwa yang menyangkut UAD, maupun kegiatan akademis mahasiswa. Sehingga orangtua, dapat memberikan support terhadap kegiatan-kegiatan putra/putrinya selama di UAD Adanya kunjungan rutin yang dilakukan oleh rektorat ke fakultas/prodi menjadi sebuah hal yang perlu dilakukan. Hal ini dimaksudkan untuk membangun 
ikatan emosional dari masing-masing fakultas/prodi/unit dengan para pemimpin. Selain itu, juga dengan melakukan hal ini, para pemimpin juga akan mengetahui apa saja yang menjadi persoalan-persoalan di level bawah sehingga mampu memberikan solusi yang tepat.

Dalam kaitannya dengan public affair ini, Humas UAD juga perlu meningkatkan kerjasama dengan berbagai pihak. Untuk meningkatkan kinerja dari masing-masing prodi/fakultas/unit. Humasdapatmengambil peran dengan mencarikan link (channeling) terkait dengan lembaga-lembaga yang bisa kita ajak untuk bekerjasama.

Banyak forum-forum ilmiah yang diselenggarakan oleh pihak luar. Humas dapat berperan aktif, untuk meningkatkan eksistensi kita di mata stakeholders eksternal. Adanya media-media komunikasi yang tepat sebagai sarana promosi dari masing-masing prodi/fakultas/unit sangat diperlukan. Jika selama ini, penggunaan media promosi yang dilaksanakan secara mandiri oleh prodi/fakultas/unit tidak teringtegrasi dengan bailk. Maka hal tersebut, tentu kurang memberikan kebermanfaatan yang lebih. Adanya keterbatasan informasi, dan kemampuan untuk mengolah pesan maupun desain menjadi sebuah persoalan yang perlu disiasati salah satunya adalah dengan adanya peran humas dalam menciptakan mediamedia promosi tersebut.

Berkunjung ke lembaga lain yang lebih baik daripada UAD tampaknya perlu dilakukan untuk meningkatkan kinerja Humas UAD. Selain untuk menjaga hubungan baik dengan lembaga lain, juga dapat dimanfaatkan sebagai sarana untuk melakukan evaluasi terhadap programprogram yang sudah kita lakukan, dan apa yang perlu kita lakukan ke depannya.

\section{Strategi Public Relations UAD dalam menjalin Komunikasi dengan Stakeholders}

Komunikasi Humas UAD dengan fakultas selama ini terjalin melalui humas di masing-masing fakultas. Melalui Humas
Fakultas, Humas UAD bisa mengetahui berbagai kegiatan yang sedang dilaksanakan oleh fakultas. Namun demikian, Humas UAD diharapkan dapat pula mengintensifkan komunikasi dengan para pimpinan di tingkat fakultas.

Hal tersebut, dimaksudkan untuk melakukan check and balancing terkait dengan informasi-informasi yang diberikan oleh Humas UAD kepada Humas Fakultas. Terkait dengan sejauhmana pelaksanaannya, dan bagaimana partisipasi dari pimpinan terhadap program-program yang akan dijalankan. Selain itu juga, supaya para pimpinan fakultas bisa memberikan support, dan masukan terhadap apa yang seharusnya bisa dilakukan untuk meningkatkan publisitas di tingkat fakultas ini.

Beberapa diantara humas fakultas yang seharusnya diharapkan dapat menjadi jembatan komunikasi antara universitas dengan fakultas tampaknya ada yang masih belum terjalin dengan baik. Mengingat ada beberapa humas fakultas yang kurang komunikatif untuk menyampaikan program-program kehumasan kepada para pimpinan fakultas, sehingga para pimpinan tidak mengetahui informasi dengan baik. Oleh karenanya, dengan adanya intensitas komunikasi yang dilakukan langsung oleh Humas UAD kepada fakultas, diharapkan dapat mengurangi hal tersebut.

Prodi yang notabene berada di bawah Fakultas, tentu diharapkan pula untuk selalu mengupdate informasi-informasi di tingkat fakultas, tidak terkecuali dengan programprogram kehumasan. Sehingga akan adanya sinergitas yang baik antara program kehumasan di tingkat prodi, dengan fakultas, maupun dengan universitas.

Sementara itu komunikasi Humas UAD dengan lembaga/biro di lingkungan UAD selamaini kurang berjalan dengan baik, dalam artian belum ada staff yang memfasilitasi hal ini,seperti halnya di tingkat fakultas yang mempunyai humasnya masing-masing. Oleh karenanya, kebutuhan komunikasi dan informasi di tingkat Biro/Lembaga belum dapat diwujudkan dengan maksimal. 
Pertemuan-pertemuan rutin baik formal dan normal perlu dilakukan untuk menjembatani hal ini, seperti halnya focus group discussion yang dijalankan beberapa waktu terakhir untuk kebutuhan penelitian ini dapat menjadi agenda rutin yang bisa diselenggarakan.

Komunikasi dengan mahasiswa hendaknya dapat dijalankan secara dua arah, yang akan saling berinteraksi untuk memberikan timbal balik. Penggunaan media-media komunikasi (media sosial) dapat dijalankan untuk mewujudkan hal ini. Jika selama ini, banyak diantara mahasiswa yang tidak bagaimana memberikan masukan/saran/kritik kepada kampus, dan justru memilih strategi yang kurang tepat (blow up di media, maupun demonstrasi) yang justru dapat menurunkan citra UAD sendiri. Tentu dengan adanya pengoptimalan penggunaan media komunikasi resmi yang dijalankan oleh kampus melalui humas UAD hal tersebut dapat ditanggulangi. Sehingga mahasiswa terfasilitasi dengan baik, akan kebutuhan komunikasi dan informasi yang selayaknya mereka terima.

Website sebagai salah satu media komunikasi global yang tidak hanya dikonsumsi oleh masyarakat Indonesia saja, namun masyarakat dunia menjadi suatu yang perlu diperhatikan Misalnya saja dengan membuat website multi bahasa. Dengan adanya feature bilingual di dalam website, tentu akan memudahkan orang asing untuk menerima informasi dari UAD. Humas dapat mengambil peran di sini, harapannya tidak hanya website universitas semata, namun juga website fakultas.

Adanya kompetisi yang diselenggarakan oleh Humas UAD untuk menyemarakkan pengelolaan website di tingkat fakultas dapat dilakukan sebagai sebuah strategi baru yang selama ini belum pernah dilakukan. Dengan adanya kompetisi tersebut, diharapkan masing-masing fakultas dapat mempunyai motivasi untuk melakukan pengoptimalan pengunaan dan pengembangan websitenya.

Jika selama ini reward hanya diberikan kepada para penulis di media massa. Sehingga menyebabkankurangberkembangnyaartikel- artikel popular di media baru (internet) maka hal ini dapat menjadi terobosan yang bisa dilakukan. Mengingat sekarang ini, media baru justru lebih efektif dan lebih luas cakupan wilayahnya dibandingkan dengan media massa. Sehingga adanya peningkatan kuantitas karya-karya dosen di sana dapat ditingkatkan, salah satunya strategi yang bisa dilakukan untuk memberikan motivasi adalah dengan memberikan reward.

Banyak informasi yang beredar namun tidak banyak yang terpublikasi dengan baik. Oleh karenanya, intensitas informasi di dalam website dapat lebih ditingkatkan lagi. Sehingga berbagai informasi dapat diterima dengan cepat dan mudah oleh masingmasing stakeholders.

Saat ini jurnalisme warga (citizen journalism) menjadi sebuah trend tersendiri. Di tengah krisis kepercayaan publik dengan media-media mainstream akibat adanya kepentingan media itu sendiri, citizen journalism menjadi sebuah solusi yang bisa dilakukan.

Dosen sebagai salah satu agent of change terhadap dinamika kehidupan yang ada dapat mengoptimalkan perannya melalui citizen journalism ini. Di dalam citizen journalism yang dibuat, para dosen bisa memberikan gagasan, pendapat, ide, maupun kritik terhadap isu-isu global yang sedang terjadi. Selain untuk meningkatkan reputrasi diri, tentu hal tersebut juga bermanfaat untuk meningkatkan reputasi lembaga.

Humas dapat mengambil peran di sini, dengan mendorong dan menciptakan wadah bagi para dosen untuk menghasilkan sebuah berita yang netral tidak tertumpangi oleh kepentingan-kepentingan lainnya.

Selama ini Humas UAD nampaknya masih kurang optimal dalam masalah pendokumentasian berita yang dipublish melalui media. Bukan hanya sekedar memberikan informasi bahwa artikel yang dibuat oleh salah satu dosen berhasil di muat di media massa, namun juga melakukan kliping terhadap pemberitaan-pemberitaan UAD di masing-masing media setiap harinya. 
Dengan hal tersebut, Humas UAD tentu akan lebih mudah melakukan monitoring terhadap pemberitaan yang dimunculkan. Terkait dengan bagaimana isi berita yang ditampilkan di media, bagaimana tata letak, gaya bahasa, pemilihan kata-kata, dan lain sebagainya.

Banyak media-media sosial atas nama UAD yang bermunculan. Setelah di kroscek, ternyata akun-akun media sosial tersebut dikelola oleh pihak-pihak yang kurang bertanggung jawab. Sehingga justru menjatuhkan kredibilitas UAD sendiri di mata masyarakat.

Membuat media sosial resmi baik di tingkat universitas, fakultas, prodi, maupun biro menjadi sebuah solusi untuk mengatasi permasalahhan ini. Selain itu media-media tidak resmi yang memang sudah lebih dahulu ada dapat dilakukan monitoring terkait bagaimana pemanfaatan dan pengelolaannya sehingga tidak kontradiksi dengan media sosial resmi yang nantinya akan dibentuk secara terintegrasi.

Beberapa fakultas memang telah memiliki media sosial yang cukup baik tidak hanya pada desainnya semata namun juga pada intensitas beritanya. Namun banyak diantara fakultasyang belum berjalan dengan baik. Adanya reward yang diberikan kepada reporter yang telah berhasil melakukan pengelolaan dengan baik tentu dapat dilakukan untuk memotivasi yang belum aktif. Jika selama ini sudah ada reward, maka perlu dilakukan evaluasi terhadap kelayakan reward yang diberikan dengan beban kerja yang dilakukan oleh para reporter. Selain itu, ketepatan waktu dalam memberikan reward juga perlu diperhatikan. Sehingga jangan sampai hal tersebut justru menjadi penghambat dari para reporter untuk membangun media sosialnya.

Tidak hanya meningkatkan kuantitas terhadap content-content yang diberikan di media social, namun juga harus mulai diperhatikan bagaimana keberagaman dari konten yang ditampilkan. Dengan adanya variasi konten yang ditampilkan (tidak hanya sebatas pada informasi saja, namun juga bisa dimanfaatkan untuk mempersuasi, atau bahkan memberikan hiburan bagi para penggunaa) tentu dapat meningkatkan loyalitas mereka dalam menerima kontenkonten yang ada.

Jika selama ini media-media sosial yang ada belum terintegrasi dengan baik, maka upaya untuk mengintegrasikannya ke dalam website universitas menjadi suatu hal yang juga perlu untuk segera dilakukan. Dengan adanya pengintegrasiaan tersebut, tentu akan memudahkan kita dalam melakukan proses monitoring.

Media lain yang perlu diperhatikan pengelolaannya media luar ruang sebagai saran promosi UAD. Bukan persoalan mudah untuk memilih media komunikasi yang tepat untuk melakukan promosi. Ada proses survey yang harus dijalankan, untuk mengetahui karakteristik masyarakat, di mana di sana akan kita tempatkan media promosi kita (spanduk, baliho, billboard, maupun umbul-umbul). Melalui proses tersebut, maka Humas akan dapat memilih media komunikasi yang lebih tepat, bukan hanya sekedar keindahan desainnya saja namun juga pesan yang ingin disampaikan. Humas sebagai bagian yang dianggap paling dekat dengan masyarakat, dapat mengambil bagiannya.

Membuat sebuah tagline yang menggambarkan kampus UAD, menjadi sebuah strategi periklanan yang bisa dilakukan. Hal tersebut dimaksudkan untuk menciptakan pesan komunikasi yang kreatf dan inovatif sesuai dengan karakteristik UAD itu sendiri, bukan hanya sekedar menyampaikan informasi (pendaftaran mahasiswa baru) yang justru kurang efektif, namun dengan adanya tagline yang kita tampilkan tentu memjadi ide yang bisa dikembangkan untuk menarik perhatian publik. Berikut ini adalah salah satu contoh media luar ruang UAD (baliho), yang di pasang di salah satu ruas jalan di Yogyakarta: 


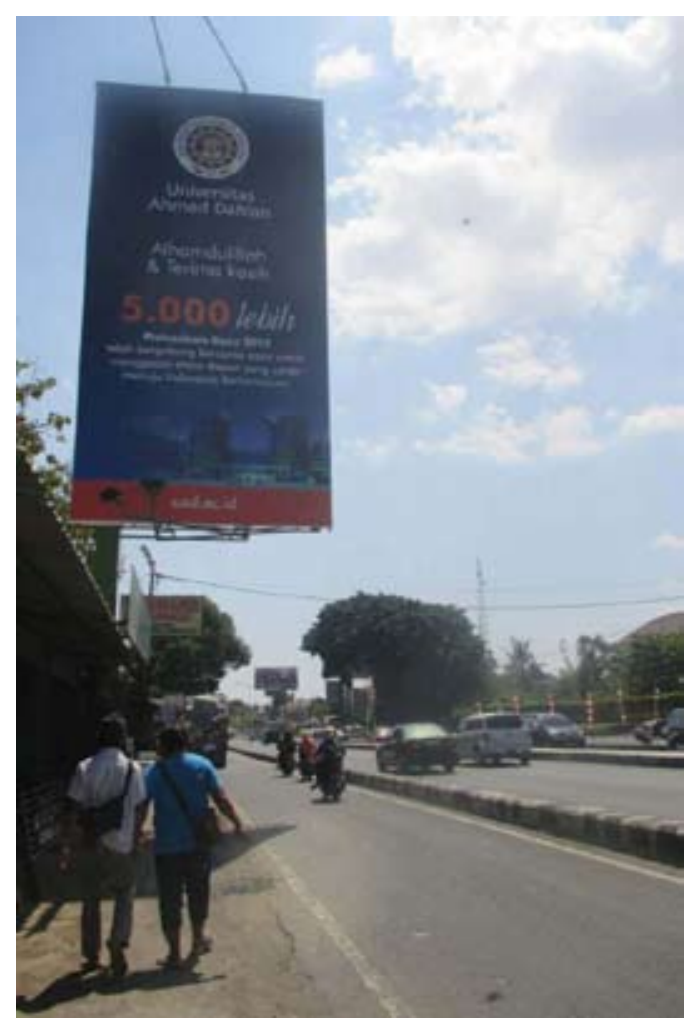

Media-media luar ruang UAD yang lebih bersifat image building, seperti di atas nampaknyajustru perlu lebih dikembangkan. Selama ini, media-media luar ruang UAD lebih banyak menginformasikan mengenai pendaftaran mahasiswa baru. Iklan tersebut, memang tidaklah salah. Hanya saja memilihan pesan yang terkesan sangat padat, sehingga justru menyulitkan orang untuk membaca nampaknya menjadi suatu hal yang perlu diperhatikan.

Media luar ruang yang bersifat image building yang singkat pesan namun tetap syarat makna tersebut justru akan lebih mengena dan mudah diingat oleh masyarakat. Sehingga justru masyarakat akan lebih mengenal UAD dengan baik, dibandingkan hanya sekedar informasi mengenai pendaftaran mahasiswa baru.

Dalam konsep pemasaran, hal terpenting yang bisa dilakukan pengiklan melalui media yang dibuatnya adalah menciptakan interest khalayak. Dengan pemilihan pesan yang pas, singkat, syarat makna, tentu akan mudah diingat oleh khalayak. Dalam kasus UAD, jika UAD bisa mengemas pesan iklan dengan baik melalui media luar ruangnya maka tentu masyarakat akan lebih tertarik untuk mengali informasi lebih mendalam. Nah informasi yang lebih mendalam inilah, yang bisa difasilitasi melalui website ataupun media komunikasi lainnya.

\section{SIMPULAN}

Setelah melakukan penelitian ini, peneliti dapat menarik kesimpulan mengenai peran Humas UAD untuk meningkatkan loyalitas stakeholders UAD, adalah, dalam kaitannya dengan melakukan pengelolaan terhadap kehumasan di UAD, Humas dapat mengambil peran untuk senantiasa meningkatkan publisitas di lingkungan UAD. Hal ini dapat dilakukan dengan membuat berbagai event yang mampu menarik perhatian dari para media. Event-event yang diselenggarakan tersebut, hendaknya mampu dikoordinasikan dengan baik dengan seluruh stakeholders UAD sendiri (pimpinan, fakultas, prodi, mahasiswa, maupun karyawan). Peningkatkan publisitas juga dapat dilakukan dengan menyelenggarakan berbagai pelatihan penulisan baik akademik, populer, maupun berita/artikel untuk para stakeholders. Pembuatan kalender kegiatan juga penting untuk dillakukan, agar berbagai kegiatan yang dilakukan baik di tingkat universitas, fakultas, prodi, maupun mahasiswa dapat terkoordinasi dengan baik.

Dalam kaitannya dengan melakukan komunikasi dengan para stakeholders di UAD, Humas dapat mengambil peran untuk senantiasa melakukan komunikasi intens tidak hanya secara horizontal, namun juga vertikal. Dalam hal ini, Humas harus berperan untuk menjembatani arus komunikasi antara pimpinan (rektorat) dengan para stakeholders. Mengingat selama ini banyak diantara stakeholders yang tidak mengetahui berbagai kebijakan yang diambil di tingkat atas. Dengan demikian, berbagai kebijakan yang diambil dapat diketahui oleh seluruh stakeholders, sehingga akan adanya support dari para stakeholders itu sendiri. Humas juga diharapkan dapat memfasilitasi pertemuanpertemuan rutin antara pimpinan dengan para stakeholders, maupun pertemuan rutin humas sendiri dengan para stakeholders 
lainnya.

Dalam kaitannya dengan melakukan pengelolaan media komunikasi, Humas UAD dapat membantu dan mengkoordinir pembuatan/pengelolaan media komunikasi baik di tingkat pusat/unit. Penyediaan sumber daya manusia, yang mampu melakukan pengelolaan media komunikasi juga merupakan sebuah strategi yang bisa dilakukan untuk melakukan pengelolaan media komunikasi dengan baik dan intens. Dalam kaitannya dengan media luar ruang, Humas UAD juga diharapakan dapat mengelola media luar ruang yang kreatif dengan membuat pesan-pesan komunikasi yang mampu menarik perhatian khalayak (profokatif, promotif, dan tidak monoton).

Adapun beberapa saran yang bisa peneliti berikan terkait dengan peran humas UAD dalam kaitannya untuk meningkatkan loyalitas stakeholders, adalah sebagai berikut, adanya peran aktif dari stakeholders untuk mengkomunikasi berbagai permasalahan komunikasi yang ada kepada Humas UAD. Adanya keterbasan sumber daya manusia di HumasUADsendiri,tentumenyebabkantidak semua kebutuhan komunikasi dari masingmasing unit (fakultas, prodi, mahasiswa, maupun karyawan) dapat dipenuhi dengan baik. Oleh karenanya, peran aktif dari stakeholders diperlukan. Dengan demikian Humas UAD, mampu berperan aktif dalam menjembatani kebutuhan komunikasi dan informasi ini.

Support system dari pimpinan sangat diperlukan dalam kaitannya dengan pengembangan kinerja Humas UAD untuk meningkatkan loyalitasstakeholders UAD ini. Support system ini tidak hanya secara materiil (penyediaan anggaran) semata, namun juga moril. Dalam hal ini adanya peran aktif/ keterlibatan dari para pimpinan dalam setiap kegiatan/program yang diselenggarakan oleh Humas UAD.

\section{DAFTAR PUSTAKA}

Cutlip, M Scott, Center H, Allen dan Broom M, Gleen. (2006). Effective Public Relations. . Jakarta: Kencana Prenada Media Grup.

DeVito, Joseph A. (2002). Komunikasi Antar Manusia, Kuliah Dasar-Edisi Kelima. Jakarta: Professional Books.

Effendy, Onong Uchana. (1999). Hubungan Masyarakat Modern. Jakarta: Bina Aksara.

Effendy, Onong Uchana. (2011). Ilmu Komunikasi dan Praktek. Bandung: Rosdakarya.

Iriantara, Yosal. (2004). Community Relations-Konsep dan Aplikasinya. Bandung: Simbiosa Rekatama Media.

Kasali, Rhenald. (2008). Manajemen Public Relations. Jakarta: Pustaka Grafiti Utama.

Nurudin. (2003). Komunikasi Massa. Malang: Cespu.

ShahramAmiridanBrianReif.(2013)."Internet Penetration and its Correlation to Gross Domestic Product". International Journal of Business, Humanities and Technology. Volume. 3 Nomor 2. February 2013. halaman 50-60

Wheelen, Thomas L\& Hunger,J. David. (1995). Strategic Management and Business Policy. Reading, Mass: Addison-Wesley Publishing Company. 